THOU SHALT NOT KILL 
FORDHAM UNIVERSITY PRESS NEW YORK 2015

COMMONALITIES

Timothy C. Campbell, series editor 


\section{THOU SHALT NOT KILL}

A Political and Theological Dialogue

ADRIANA CAVARERO AND

ANGELO SCOLA

Translated by Margaret Adams Groesbeck and Adam Sitze 
Copyright (C) 2015 Fordham University Press

All rights reserved. No part of this publication may be reproduced, stored in a retrieval system, or transmitted in any form or by any means-electronic, mechanical, photocopy, recording, or any other-except for brief quotations in printed reviews, without the prior permission of the publisher.

This book was originally published in Italian as Adriana Cavarero and Angelo Scola, Non Uccidere, (C) 2011 by Società editrice il Mulino, Bologna.

The translation of this work has been funded by SEPS

Segretariato Europeo per le Pubblicazioni Scientifiche

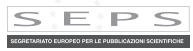

Via Val d'Aposa 7 - 40123 Bologna - Italy

seps@seps.it - www.seps.it

Fordham University Press has no responsibility for the persistence or accuracy of URLs for external or third-party Internet websites referred to in this publication and does not guarantee that any content on such websites is, or will remain, accurate or appropriate.

Fordham University Press also publishes its books in a variety of electronic formats. Some content that appears in print may not be available in electronic books.

Visit us online at www.fordhampress.com.

Library of Congress Cataloging-in-Publication Data

Cavarero, Adriana.

[Non uccidere. English]

Thou shalt not kill : a political and theological dialogue /

Adriana Cavarero and Angelo Scola ; translated by Margaret

Adams Groesbeck and Adam Sitze.-First edition.

pages $\mathrm{cm}$. - (Commonalities)

Includes bibliographical references and index.

ISBN 978-0-8232-6734-7 (cloth : alk. paper) -

ISBN 978-0-8232-6735-4 (pbk. : alk. paper)

1. Ten commandments-Murder. I. Scola, Angelo.

II. Title.

BV468o.C3813 2015

$179.7-\mathrm{dc} 23$

2015009512

Printed in the United States of America

$\begin{array}{llllllll}17 & 16 & 15 & 5 & 4 & 3 & 2 & 1\end{array}$

First edition 